Ophthalmologica 1963;146:I-VI

\title{
Contents, Vol. 146, 1963
}

\section{Index}

Âgoston, I.: Vide Gróf, P.

Altman, J.: Vide Kumstát, Z.

Andreani, D.: Vide Focosi, M.

Asayama, R.; Tsukahara, I. und Sakaue, E.:

Tierexperimentelle Untersuchungen über die antiphlogistische Wir-

kung von Tanderil 104

Balík, J.: Über die Ausscheidung der Glykose in die Tränen bei trockener

Keratoconjunctivitis 280

Basset, A.: Vide Quéré, M. A.

Benkö, É. und Sipos, I.:

Einige Fälle von Opticus-Neuritis als Begleiterscheinung der Keratoconjunctivitis epidemica 83

Beumer, L.: A Quicker Method of Embedding Eyes in Nitrocellulose of Low Viscosity

Bianchetti, M.: Herpes simplex Keratitis. Untersuchung über die Zunahme der Häu-

figkeit der Herpes simplex Keratitis 395

Biesheuvel, K.: Central Tapeto-Retinal Degeneration with Peripheral Involvement.

(Differential Diagnostic Difficulties) 238

Boros, B.: Vide Gróf, P.

BozsÓky, S.: Intraocular Antibody Production: Clinical Implications

Breukink, E. W. and Ten Doesschate, J.:

Attenuation Curves of the Human Eye under Normal and PathologicalConditions 143

Camain, R.: Vide Quéré, M. A.

Colenbrander, A.: The Influence of G-Forces on the Counter-Rolling of the Eye . . 309

Ten Doesschate, J.:

Demonstrations on the Treatment of Retinal Detachment 365

Ten Doesschate, J.:

Vide Breukink, E. W.

Dunnewold, C. J. W.:

A Retinal Acuity Direction Effect 321

Dyster-Aas, H. K. and Krakau, C. E. T.:

A Photo-Electric Instrument for Measuring the Aqueous Flare in theIntact Eye 48

Francois, J. and Neetens, A.:

Capillary Systems of the Optic Pathways

Francois, J.; Rabaey, M. and Lagasse, A.:

Electron Microscopic Observations on Choroid, Pigment Epithelium

and Pecten of the Developing Chick in Relation to Melanin Synthesis 415

Francois, J.; de Rouck, A. et Verriest, G.:

L'électro-rétinographie dans les dyschromatopsies et dans Гachro-matopsie 
Focosi, M.; Lepri, G.; Andreani, D. and Parducci, F.:

Our Present Experience with 5-iodo-2' Deoxiuridine (IDU) in Ophthalmology (with Plates I and II) $\quad 199$

Gilson, M.: Vide Weekers, R.

Grieten, J.: Vide Weekers, R.

Gróf, P.; Boros, B. et Âgoston, I.:

Le taux d'histamine tissulaire totale de Гæil de bæuf

Hamburg, A.: Pseudoglioma 355

Hellner, K. A. Die Latenz der Makro- und Mikropotentiale des optischen Cortex derKatze nach elektrischem Opticusreiz und die Beziehung zur Retino-Cortical-Zeit 124

van den Heuvel, J. E. A.:

Removal of a Cyst of the Iris together with the Lens .

Holland, G. und Thiers, H. :

Beitrag zum Glioma retinae 377

Joachim, M.: Vide Weekers, R.

Krakau, C. E. T.: Vide Dyster-Aas, H. K.

Korchmáros, I.: Ein neuer Eingriff bei Distichiasis und Trichiasis 101

Krych, J.: Vide Orlowski, W. J.

Kumstát, Z.; Pospísil, L. und Altman, J.:

Eine neue Art von Materialabnahme für die mikrobiologische Unter-suchung in der

Ophthalmologie (s.g. Abklatschtest) 209

Lagasse, A.: Vide Francois, J.

Lamers, W. P. M. A.:

Malignant Melanoma of the Cornea 353

Lazar, M.; Regenbogen, L. and Stein, R.:

Anterior Uveitis due to Chloroquine 411

Lekeux, M.: Vide Weekers, R.

Lepri, G.: Vide Focosi, M.

Lipnicki, B. B. and Skrzypczak, K. E.:

The Chance of Vitreous Heterografts in Experimental Animals . . 275

Moses, R. A.: Hydrodynamic Model Eye 137

Nagy, G. und Szarvasy, G.:

Ophthalmologische Beziehungen der Pelger-Huëtschen Kernanomalie

der Blutkörperchen

9

Neetens, A.: Vide Francois, J.

Németh, L.: Isotopical Autoplastic Repair of Palpebral Defects 242

Notter, H.: $\quad$ Pupillen-Erweiterung bei Glaukom-Kranken mit Mydriatikum Roche in niedrigen Konzentrationen 227

Orlowski, W. J. und Krych, J.:

1st das Stilling-Türk-Duane-Syndrom eine selbständige Krankheit?

II. Genetische Beweise 178

Otradovec, J.: Chorioretinitis centralis bei Leucoencephalitis subacuta sclerotisans

van Bogaert 65

Pápai, I. Cs.: Vide Szeghy, G.

Papamatheakis, N.: 
Manifestation allergique professionnelle des ophtalmologistes . . 358Parducci, F.: $\quad$ Vide Focosi, M.

PeÑa-Carrillo, J.: Histochemical Aspects of the Rabbit's Normal Cornea and of Experimental Corneal Grafts (with plates I and II) 260

Planten, J. Th. : Clinical Observation of the Oculo-Cardiac Reflex 300

Planten, J. Th. : Examination of the Epithelium of the Ciliary Body with the Help of

Fluorescence Microscopy 303

Pospísil, L.: Vide Kumstãt, Z.

Quéré, M. A.; Basset, A. et Camain, R.:

Les localisations oculaires de Tangioréticulosarcomatose de Kaposi .

Rabaey, M.: Vide Francois, J.

Regenbogen, L.: Vide Lazar, M.deRouck, A.: $\quad$ Vide Francois, J.

Sakaue, E.: Vide Asayama, R.

Sampimon, R. L. H.: New Ways of Treating Keratitis Herpetica 314

Schlesinger, F. G.: Hypophyseal Stalk Section in Rapidly Progressive Diabetic Retinopathy 361

Schweitzer, N. M. J. and Troelstra, A.:

On the Physiological Standardization of the Light Source in Electro-

retinography 114

Schweitzer, N. M. J. and Troelstra, A.:

Dark Adaptation, Measured by Electroretinography 363

Sie-Boen-Lian : Cultivation of Virus in a Case of Sympathetic Ophthalmia ....

Sipos, I.: $\quad$ Vide Benkö, É.

Stein, R.: $\quad$ Vide Lazar, M.

Szarvasy, G.: Vide Nagy, G.

Szeghy, G.; Pápai, I. Cs. und Vas, Z.:

Zur Kenntnis der Augenverletzung durch Bienenstich

Szrzypczak, K. E.: Vide Lipnicki, B. B.Thiers, H.: Vide Holland, G.

Timm, G.: $\quad$ Oxalose und Auge 1

Timm, G.: $\quad$ Die Histologie der Lidaspergillose 250

Troelstra, A.: Vide Schweitzer, N. M. J.

Tsukahara, I.: Vide Asayama, R.

Valk, L. E. M.: $\quad$ Successes and Set-back in the Treatment of Diabetic Retinopathy

with Anabolic Steroids during the Last Five Years 325

Vas, Z.: Vide Szeghy, G.

Velický, G.: Erfahrungen mit der kornplexen klimatischen Behandlung der endo-

genen Augenentzündungen 34

Verriest, G.: Vide Francois, J.

Weekers, R.; Gilson, M. et Joachim, M.:

Mesure des petits angles de strabisme au moyen d'une technique

photographique

Weekers, R.; Grieten, J. et Lekeux, M.:

Etude des dimensions de la chambre antérieure de Гæil humain.

4e Partie: L'intumescence cristallinienne et ses consequences chirugi-

cales 57

Wider, S.: $\quad$ Effect of Hormones on Eyelid Disjunction in the Rat 
Letter to the Editor 295

Verhandlungsberichte - Proceedings - Congrès

Netherlands Ophthalmological Society, 150th Meeting, Utrecht, September 15th and 16th, 1962 299

Ophthalmological Society of the United Kingdom, 83rd Annual Congress, London, April 3rd, 4th and 5th, 1963 367

Buchbesprechungen - Book Reviews - Livres Nouveaux 134, 214, 295, 371, 438

C. Competition/Dr. Heinz Karger Memorial Foundation - Preisausschreiben/Dr. Heinz KargerGedächtnis-Stiftung - Concours/Fondation Commemorative Dr. Heinz Karger 297

Varia 135

214

438 